\title{
ARTICLE Structure-based design of a hyperthermostable AgUricase for hyperuricemia and gout therapy
}

\author{
$\mathrm{Yi}_{\text {Shi }}{ }^{1}$, Ting Wang ${ }^{1,2,3}$, X. Edward Zhou ${ }^{4}$, Qiu-feng Liu ${ }^{1}$, Yi Jiang ${ }^{1,2}$ and H. Eric $\mathrm{Xu}^{1,2,3,4}$
}

\begin{abstract}
Arthrobacter globiformis Uricase (AgUricase) is a homotetrameric uricase with the potential for therapeutic use in treating hyperuricemia-related diseases. To achieve sufficient therapeutic effects, it is essential for this enzyme to have high thermostability and long half-life in physiological condition. To improve the thermostability of this enzyme, we introduced a series of cysteine pair mutations into the AgUricase subunits based on its structural model and studied the thermostability of the mutant enzymes with introduced disulfide bridges. Two intersubunit cysteine pair mutations, K12C-E286C and S296C-S296C, were found to markedly increase the melting temperatures of the corresponding mutant enzymes compared with WT AgUricase. The crystal structure of the K12C-E286C mutant at $1.99 \AA$ resolution confirmed the formation of a distinct disulfide bond between the two subunits in the dimer. Structural analysis and biochemical data revealed that the C-terminal loop of AgUricase was flexible, and its interaction with neighboring subunits was required for the stability of the enzyme. We introduced an additional intersubunit K244C-C302 disulfide bond based on the crystal structure of the K12C-E286C mutant and confirmed that this additional disulfide bond further stabilized the flexible C-terminal loop and improved the thermostability of the enzyme. Disulfide cross-linking also protected AgUricase from protease digestion. Our studies suggest that the introduction of disulfide bonds into proteins is a potential strategy for enhancing the thermostability of multimeric proteins for medical applications.
\end{abstract}

Keywords: uricase; thermostability; disulfide cross-linking; crystal structure

Acta Pharmacologica Sinica (2019) 40:1364-1372; https://doi.org/10.1038/s41401-019-0269-x

\section{INTRODUCTION}

Uricase or urate oxidase (EC 1.7.3.3) catalyzes the oxidation of uric acid to 5-hydroxyisourate and hydrogen peroxide $\left(\mathrm{H}_{2} \mathrm{O}_{2}\right)$ [1]. Subsequent hydrolysis and decarboxylation lead to the formation of allantoin, which is easily excreted by the kidney in most prokaryotic and eukaryotic organisms [1]. However, all five genera of hominoids (human, chimpanzee, gorilla, orangutan, and gibbon) have lost uricase activity during hominoid evolution [2]. Thus, elevated levels of uric acid in the blood (hyperuricemia) can result in urate crystal deposition, which is involved in gout, chronic kidney disease, tumor lysis syndrome (TLS), hypertension and various cardiovascular diseases [1, 3].

Arthrobacter globiformis Uricase (AgUricase) is a homotetrameric enzyme composed of four identical $34 \mathrm{kDa}$ subunits with high expression levels in Escherichia coli and excellent activity at neutral $\mathrm{pH}$; thus, it has the potential for therapeutic applications [4]. To achieve sufficient therapeutic efficacy, it is essential for this enzyme to have high thermostability and a long half-life in physiological conditions [5]. It was reported that the introduction of disulfide bonds into Bacillus sp. TB-90 uricase (Bt Uricase) via the R298C mutation increased the transition temperature by $15^{\circ} \mathrm{C}$, at which the enzyme retained $50 \%$ of its initial activity [6]. Compared with single-residue substitution, the rational design of cysteine mutations in adjacent subunits using a structural model is a more efficient method to generate disulfide bonds to stabilize proteins [7-9]. The wild-type (WT) AgUricase crystal structure has been solved (PDB entry 2YZB) and shows four identical chains that enclose a closed tunnel, and each chain consists of two tandem tunneling-fold motifs. In this study, we introduced a series of disulfide bonds between AgUricase subunits based on the WT crystal structure and identified intersubunit disulfide bonds formed in AgUricase mutants with mutations K12C-E286C and K244C using SDS-PAGE and thermal shift assays (TSA). We solved the crystal structure of the K12C-E286C mutant, which confirmed that two disulfide bonds formed between the cysteine pair K12C-E286C at the interface of two subunits within a dimer. Furthermore, our data suggested that these cysteine pair mutants retained full WT enzyme activity and also had significantly improved thermostability and heat resistance, thus providing promising therapeutic options for the treatment of hyperuricemia-related diseases.

\section{MATERIALS AND METHODS}

\section{Materials}

Uric acid, ampicillin, isopropyl $\beta$-D-l-thiogalactopyranoside (IPTG), and all media supplements were purchased from Sigma-Aldrich

${ }^{1}$ The CAS Key Laboratory of Receptor Research, VARI-SIMM Center, Center for Structure and Function of Drug Targets, Shanghai Institute of Materia Medica, Chinese Academy of Sciences, Shanghai 201203, China; ${ }^{2}$ University of Chinese Academy of Sciences, Beijing 100049, China; ${ }^{3}$ School of Life Science and Technology, ShanghaiTech University, Shanghai 201213, China and ${ }^{4}$ Laboratory of Structural Sciences, Van Andel Research Institute, Grand Rapids, MI 49503, USA

Correspondence: Yi Shi (shiyi@simm.ac.cn) or H. Eric Xu (eric.xu@simm.ac.cn)

These authors contributed equally: Yi Shi, Ting Wang

Received: 24 April 2019 Accepted: 8 June 2019

Published online: 28 June 2019 
(St. Louis, MO). All of the other chemicals were local products of analytical grade.

Molecular cloning and site-directed mutagenesis

The complementary DNA (cDNA) of AgUricase (UniProtKB entry sequence DOVWQ1) was synthesized by Synbio Tech. The CDNA of AgUricase was cloned into the pET21 vector. An $8 X$ His tag was introduced into the $\mathrm{N}$ terminus of AgUricase for affinity purification. The site-specific mutagenesis of AgUricase was conducted by overlap extension using polymerase chain reaction [10]. The primer sequences are listed in Supplementary Table S1. The mutations were verified by DNA sequencing.

Protein expression and purification

The pET21-8X His-AgUricase plasmid was transformed into BL21 (DE3) cells. The cells were grown in Lysogeny broth medium with appropriate antibiotics in a flask at $37^{\circ} \mathrm{C}$ with shaking at $225 \mathrm{r} / \mathrm{min}$, and protein expression was induced at an $O D_{600}=1.0$ with the addition of $0.1 \mathrm{mM}$ IPTG at $16^{\circ} \mathrm{C}$ overnight. The cells were collected by centrifugation at $4000 \mathrm{r} / \mathrm{min}$ at $4{ }^{\circ} \mathrm{C}$ for $20 \mathrm{~min}$. The cell pellets were resuspended in $3 \mathrm{~mL}$ lysis buffer (Buffer A: $50 \mathrm{mM}$ Tris, pH 8.0, $400 \mathrm{mM} \mathrm{NaCl}, 25 \mathrm{mM}$ imidazole and phenylmethylsulfonyl fluoride) and lysed by sonication. After ultracentrifugation, the supernatant was loaded into a gravity column containing $5 \mathrm{~mL}$ nickel resin (GE Health) pre-equilibrated with lysis buffer. After binding at $4{ }^{\circ} \mathrm{C}$ for $2 \mathrm{~h}$, the column was washed with 10 column volume (CV) lysis buffer. The target protein was eluted with $5 \mathrm{CV}$ elution buffer $(50 \mathrm{mM}$ Tris, $\mathrm{pH} 8.0,400 \mathrm{mM} \mathrm{NaCl}$, and $500 \mathrm{mM}$ imidazole). The protein was concentrated to $\sim 5 \mathrm{mg} / \mathrm{mL}$ and further purified with a Superdex 200 Hiload $26 / 60$ gel filtration column (GE Healthcare) equilibrated with SEC buffer $(20 \mathrm{mM}$ HEPES, pH 7.5, $100 \mathrm{mM} \mathrm{NaCl}$ ). The AgUricase fractions were pooled and concentrated for the subsequent experiments. The concentration of AgUricase was quantified using a Qubit protein assay kit and a Qubit 2.0 fluorometer (Invitrogen).

\section{Thermal shift assay}

The thermostability of the uricases was evaluated by a TSA as described previously [11]. In brief, $1000 \times$ SYPRO Orange (SigmaAldrich, USA) was diluted with phosphate-buffered saline and mixed with the protein. All reactions were performed in triplicate in 384-well plates with a final volume of $10 \mu \mathrm{L}$ per well. The thermal melting curve was determined using a LightCycler 480 II Real-Time PCR System (Roche Diagnostics, Rotkreuz, Switzerland) with a ramp rate of $1{ }^{\circ} \mathrm{C}$ and a temperature range from $30^{\circ} \mathrm{C}$ to $100^{\circ} \mathrm{C}$. The melting temperatures $\left(T_{\mathrm{m}}\right)$ were calculated by fitting the sigmoidal melting curve to the Boltzmann equation using GraphPad Prism 7.0 with $R^{2}$ values $>0.99$.

\section{Uricase activity assay}

Uricase activity was assayed by monitoring the depletion of uric acid, which was detected by a decrease in absorbance at $292 \mathrm{~nm}$ in the presence of the enzyme $[4,6]$. The uricase was diluted to $1 \mu \mathrm{g} / \mathrm{mL}$ and combined with different concentrations of UA in $0.1 \mathrm{M}$ phosphate buffer (PB), pH 7.4. Absorbance measurements at $292 \mathrm{~nm}$ were recorded every $30 \mathrm{~s}$ for a period of $10 \mathrm{~min}$. The extinction coefficient for uric acid was assumed to be $1.22 \times 10^{4} \mathrm{M}^{-1} \cdot \mathrm{cm}^{-1}$. The rate of uric acid degradation $(\mu \mathrm{mol} / \mathrm{min})$ was calculated. The enzyme kinetics parameters were calculated by fitting the data to the Michaelis-Menten equation using the GraphPad Prism 7.0 program.

Heat resistance assay

The AgUricases were incubated for $30 \mathrm{~min}$ at various temperatures, and then the temperature was reduced to $25^{\circ} \mathrm{C}$, after which the residual activity was assayed using the methods described above. The data were fit according to a two-state mechanism using the following equations to determine the temperature at which the enzyme retained half of its activity $\left(T_{m}\right)$ and the van't
Hoff enthalpy $(\Delta H)$ value: [12]

$$
\begin{aligned}
& Y=f_{U} Y_{U}+f_{N} Y_{N} \\
& f_{U}+f_{N}=1 \\
& f_{U}=\frac{[U]}{[U]+[N]} \\
& K=\frac{[U]}{[D]}
\end{aligned}
$$$$
\Delta G=-R T \ln K
$$

$\Delta G=\Delta H\left(1-\frac{T}{T_{\mathrm{m}}}\right)$

where $Y$ is the experimentally measured enzymatic activity at temperature $T, Y_{\mathrm{N}}$, and $Y_{\mathrm{U}}$ are the enzymatic activity of AgUricase in the native state and the unfolded state, respectively, $f_{\mathrm{N}}$ and $f_{\mathrm{U}}$ are the fractions of protein in the native state and the unfolded state, respectively, $K$ is the apparent equilibrium constant, $\Delta G$ is the free energy change, $T_{\mathrm{m}}$ is the temperature at which the enzyme retains half of its activity, $\Delta H$ is the enthalpy change, $R$ is the gas constant and $T$ is the absolute temperature [12]. The software GraphPad Prism 7.0 was used for the data fitting.

Proteinase $\mathrm{K}$ resistance assay

AgUricases $(80 \mu \mathrm{g})$ were treated with $20 \mu \mathrm{g}$ Proteinase $\mathrm{K}$ at room temperature, and the residual activity of AgUricase at various times was assayed using the methods described above.

Protein crystallization, structure determination, and refinement The K12C-E286C AgUricase crystals were obtained with the sitting drop method in a buffer containing $12 \%(\mathrm{w} / \mathrm{v})$ polyethylene glycol 3350 and $0.1 \mathrm{M}$ sodium malonate $(\mathrm{pH}$ 5.0). The crystals were transferred to a reservoir solution with $20 \%$ glycerol, which served as a cryoprotectant, before being flash-frozen in liquid nitrogen. The diffraction data for the K12C-E286C AgUricase crystals were collected at beamline BL19U1 at the Shanghai Synchrotron Radiation Facility (Shanghai, China). The X-ray diffraction data were integrated and scaled using the HKL3000 program [13]. The structure of $\mathrm{K} 12 \mathrm{C}-\mathrm{E} 286 \mathrm{C}$ AgUricase was initially solved by molecular replacement using Phenix.phaser [14] with the wildtype AgUricase structure (PDB entry: 2YZB) as the starting model. The model was manually adjusted in COOT [15] and refined with Phenix.refine [16] and CCP4 [17]. The data and refinement statistics are listed in Supplementary Table S3.

\section{RESULTS}

Cysteine mutations K12C-E286C and S296C introduced disulfide bonds between the AgUricase subunits

AgUricase is a homotetramer composed of four identical subunits. High thermostability of this enzyme is a highly desirable property that is correlated with its tolerance to heat denaturation, which involves a two-step process consisting of the dissociation of the tetramer into dimers and the dissociation of the dimers into monomers, followed by the unfolding of the monomers [18-21]. Based on the crystal structure, we designed a series of cysteine mutations to introduce cysteine pairs at the dimer interface that would form disulfide bonds that would crosslink the subunits to prevent the disassociation and unfolding of the multimeric enzyme (Fig. 1 and Supplementary Table S2). The formation of intersubunit disulfide bonds was verified by sodium dodecyl sulfate polyacrylamide gel electrophoresis (SDS-PAGE)SDS-PAGE 

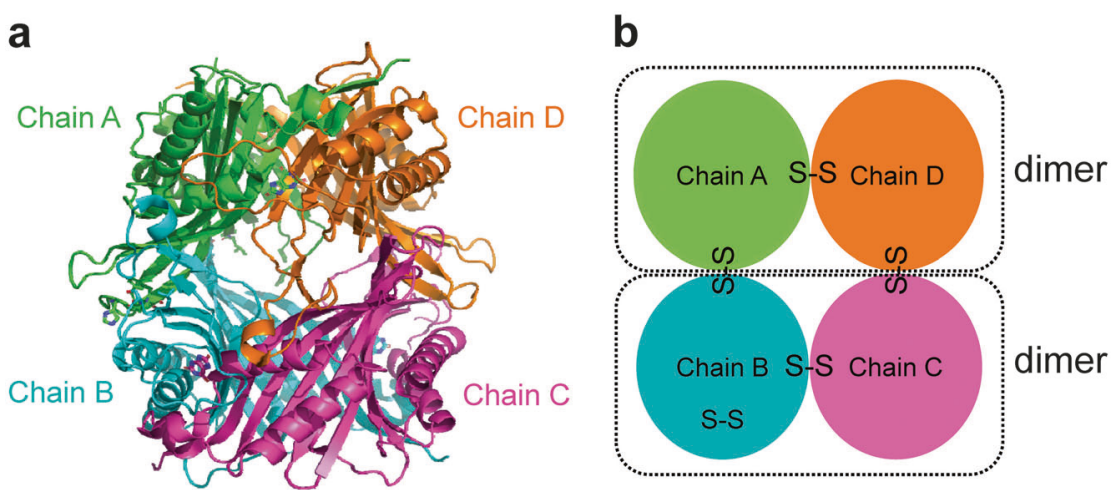

Fig. 1 Introduction of disulfide bonds to stabilize AgUricase based on its crystal structure. a The introduction of disulfide bonds based on the structural model of WT AgUricase (PDB code 2YZB). Chain A, green; chain B, cyan; chain C, magenta; chain D, orange. b Cartoon model showing the disulfide bond design. Monomer-monomer, dimer-dimer, and intra-subunit disulfide bonds were generated by introducing cysteine pair mutations based on the crystal structure of WT AgUricase
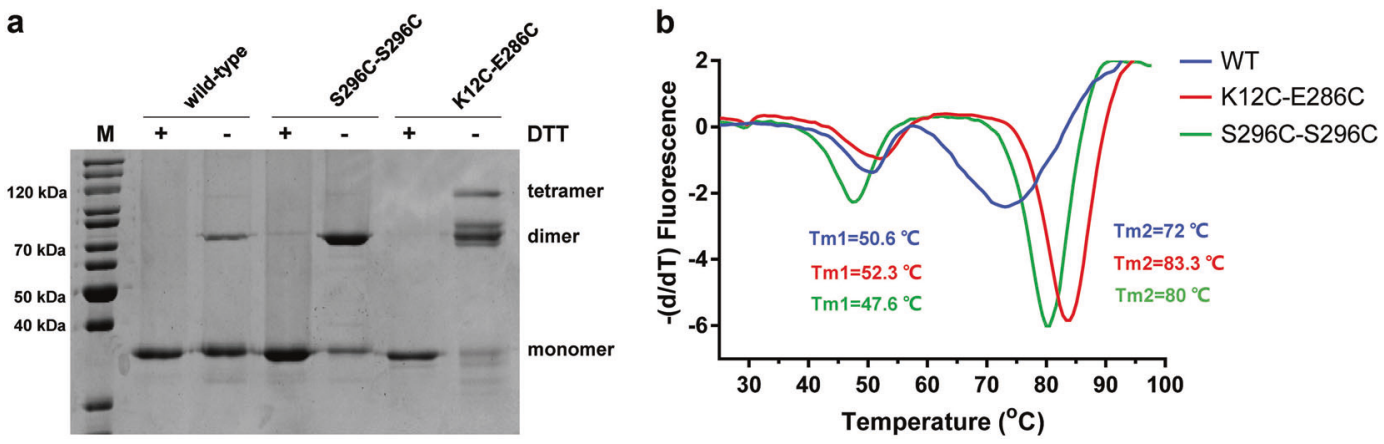

Fig. 2 Cysteine mutations K12C-E286C and S296C introduced disulfide bonds between the AgUricase subunits and significantly improved the thermostability of AgUricase. a K12C-E286C and S296C-S296C AgUricase mutants formed disulfide bonds between subunits. Disulfide bridge formation was verified by SDS-PAGE with and without DTT. $\mathbf{b}$ Thermal shift assays (TSA) of AgUricases. The thermal stabilities of wildtype (blue), K12C-E286C (red), and S296C-C302S (green) mutant AgUricase were evaluated by TSA using the method described in the methods section

with and without the reducing reagent dithiothreitol (DTT) [21] (Fig. 2a and Supplementary Fig. S1). Wild-type (WT) AgUricase showed a single band at $35 \mathrm{kDa}$ in both the presence and absence of DTT, which corresponded to the AgUricase monomer (Fig. 2a and Supplementary Fig. S1). Many of the cysteine pair mutants showed a weak band at $70 \mathrm{kDa}$ during SDS-PAGE analysis that was similar to that of WT AgUricase, indicating that the cysteine pairs did not form proper disulfide bonds between the two subunits (Supplementary Fig. S1). However, the F125C/L156C and K29/E267C mutants did not show any distinct band corresponding to this protein on the SDS-PAGE gel, suggesting that there was no soluble expression of these mutants (Supplementary Fig. S1). Interestingly, K12C-E286C and S296C-S296C showed dimer bands at $70 \mathrm{kDa}$ in the absence of DTT, suggesting that proper disulfide bonds between the AgUricase subunits were successfully introduced through the K12C-E286C and S296C mutations (Fig. 2a). WT AgUricase also showed a weak dimer band at $70 \mathrm{kDa}$ in the absence of DTT, which is probably owing to intersubunit crosslinking via the $\mathrm{C}$-terminal residue $\mathrm{C} 302$ since the $\mathrm{C}$ termini of the subunits in an AgUricase dimer are close to each other, as shown in the crystal structure. To avoid the nonspecific cross-linking of C302 with S296C, we introduced the additional mutation C302S into the S296C mutant. Thus, the S296C mutant in this study actually contained two mutations (S296C/C302S).

Intersubunit disulfide bonds improved the thermostability of AgUricase

A TSA experiment was conducted to further investigate the effect of the introduced intersubunit disulfide bonds on the thermostability of AgUricase. The TSA curves of WT AgUricase showed two distinct transition peaks. Double-peaked transitions are often interpreted as indicating the existence of multiple structural domains or subunits within a molecule that unfold independently [22]. The first peak corresponds to the disassociation of the tetramer into dimers, and the second peak represents the disassociation of the dimer into monomers [4, 22]. The K12C-E286C mutations delayed the first transition, whereas the S296C-S296C mutations sped it up, suggesting that K12C-E286C prevented tetramer disassociation, whereas S296C did not (Fig. 2b). This observation is consistent with the results showing that the K12C-E286C mutant formed both monomer-monomer and dimer-dimer disulfide cross-links, whereas S296C formed only monomer-monomer disulfide cross-links. As shown in Fig. $2 \mathrm{~b}$, the second peak of the transition of the K12C-E286C and S296C-S296C mutants shifted to $83.3^{\circ} \mathrm{C}$ and $80^{\circ} \mathrm{C}$, respectively, compared with that of the WT enzyme, which occurred at $72^{\circ} \mathrm{C}$, indicating that both the $\mathrm{K} 12 \mathrm{C}-\mathrm{E} 286 \mathrm{C}$ and S296C mutations strengthened the interaction between the two subunits within the dimers and delayed the dissociation of the dimer in the enzyme into monomers. Other cysteine pair mutations we introduced did not improve the thermostability of the enzyme based on TSA analysis, except H123C-S158C, for which the TSA profile showed that the second peak was shifted from $72^{\circ} \mathrm{C}$ to $74.5^{\circ} \mathrm{C}$, whereas the first peak disappeared, indicating that the $\mathrm{H} 123 \mathrm{C} / \mathrm{S} 158 \mathrm{C}$ mutations slightly strengthened the monomer-monomer interaction but weakened the dimer-dimer interaction (Supplementary Fig. S2). Therefore, we focused our study on the K12C-E286C and S296C-S296C mutations. 


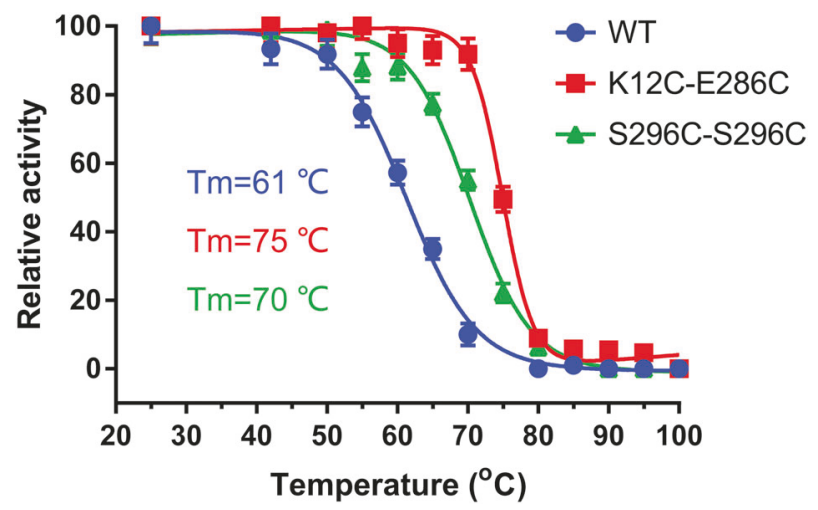

Fig. 3 K12C-E286C and S296C-S296C mutations significantly improved the heat resistance of AgUricase. The relative activity of wild-type (circle), K12C-E286C (square), and S296C-C302S (triangle) mutant AgUricase were measured after $30 \mathrm{~min}$ of incubation at various temperatures. The temperatures at which the enzymes retained half of their activity $\left(T_{\mathrm{m}}\right)$ were determined by fitting the curve to the equations (1-6) using GraphPad Prism 7 with $R^{2}$ values $>0.99$. The data are presented as the mean \pm standard error of the means (SEM) of at least three independent experiments

K12C-E286C and S296C-S296C mutations significantly improved the heat resistance of AgUricase

We tested the effect of disulfide cross-linking on the heat resistance of AgUricase. The activities of WT and mutant AgUricase were assayed at various temperatures, and the residual activity data were fit to the equations (1-6) [23]. The $T_{m}$ value is used to define the temperature at which half of the total enzyme is denatured [24]. The K12C-E286C and S296C-S296C mutants showed markedly increased heat resistance (Fig. 3). The $T_{\mathrm{m}}$ values of the K12C-E286C and S296C-S296C mutants were $14{ }^{\circ} \mathrm{C}$ and $9{ }^{\circ} \mathrm{C}$ higher, respectively, than those of the wild-type enzyme $\left(61^{\circ} \mathrm{C}\right.$ vs $75^{\circ} \mathrm{C}$ and $61^{\circ} \mathrm{C}$ vs $70^{\circ} \mathrm{C}$ ) (Fig. 3). These increases in thermal resistance were likely due to the formation of intersubunit disulfide bridges [25-27].

Disulfide cross-linking did not affect the catalytic efficiency of AgUricase

We tested the effect of disulfide cross-linking on the enzyme kinetics of AgUricase. The K12C-E286C mutant showed a $k_{\text {cat }}$ of $5.8 \pm 0.4 \mathrm{~s}^{-1}$ and a $K_{\mathrm{m}}$ value of $104.5 \pm 10.2 \mu \mathrm{M}$, and the S296C/C302S mutant exhibited a $k_{\text {cat }}$ of $5.89 \pm 0.3 \mathrm{~s}^{-1}$ and a $K_{\mathrm{m}}$ value of $126.8 \pm 17 \mu \mathrm{M}$; the $k_{\text {cat }} / K_{\mathrm{m}}$ values were $(5.55 \pm 0.3) \times 10^{4} \mathrm{~s}^{-1} \cdot \mathrm{M}^{-1}$ and $(4.64 \pm 0.2) \times$ $10^{4} \mathrm{~s}^{-1} \cdot \mathrm{M}^{-1}$, respectively. All these kinetic parameters of the mutants were close to those of the wild-type enzyme $\left(k_{\text {cat }}=\right.$ $6.64 \pm 0.3 \mathrm{~s}^{-1}, \quad K_{\mathrm{m}}=140.3 \pm 18.3 \mu \mathrm{M}$, and $k_{\mathrm{cat}} / K_{\mathrm{m}}=(4.73 \pm 0.2) \times$ $10^{4} \mathrm{~s}^{-1} \cdot \mathrm{M}^{-1}$ ) (Fig. 4). These results suggested that disulfide crosslinking did not greatly affect the catalytic efficiency of AgUricase.

Disulfide cross-linking hindered the disassociation of tetramer and dimer

To confirm the formation of disulfide bond cross-linking and further investigate its effects on the thermostability of AgUricase, we solved the crystal structure of the K12C-E286C mutant at 1.99 $\AA$ resolution (Fig. 5, PDB entry 6OE8). The crystal structure of K12C-E286C clearly showed four disulfide bonds between C12 and C286 in neighboring subunits (Fig. 5a). K12C in subunit A formed a disulfide bond with E286C in subunit D. K12C in subunit D also formed a disulfide bond with E286C in subunit A. Similar disulfide bonds were formed between the introduced cysteine residues in subunit $B$ and subunit $C$. The $\mathrm{Ca}-\mathrm{Ca}$ distance between residue 12 and residue 286 remained $5.4 \AA$, which is the same as that found in the wild-type enzyme. The parameters of these disulfide bonds are listed in Supplementary Table S4.

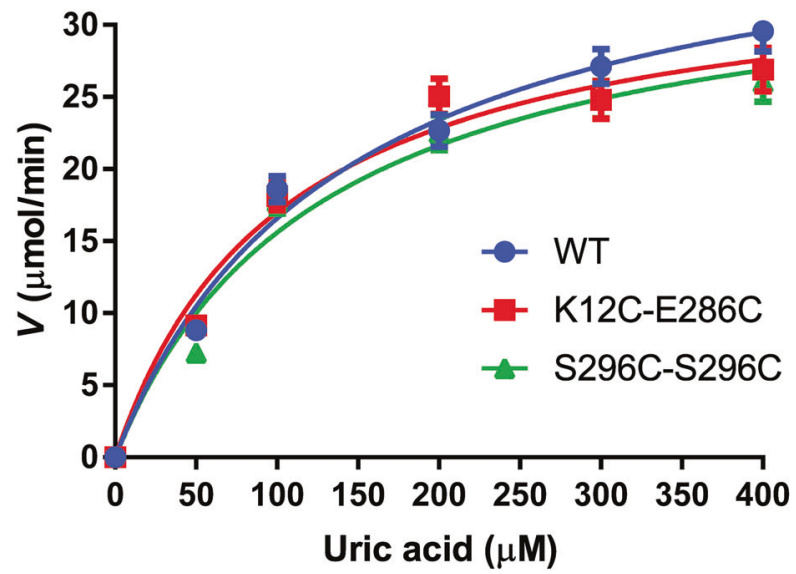

\begin{tabular}{lccc}
\hline & $k_{\text {cat }}\left(\mathrm{s}^{-1}\right)$ & $K_{m}(\mu \mathrm{M})$ & $k_{\text {cat }} / K_{m}\left(\mathrm{~s}^{-1} \cdot \mathrm{M}^{-1}\right)$ \\
\hline WT & $6.64 \pm 0.3$ & $140.3 \pm 18.3$ & $4.73 \times 10^{4}$ \\
K12C-E286C & $5.8 \pm 0.4$ & $104.5 \pm 10.2$ & $5.55 \times 10^{4}$ \\
S296C-S296C & $5.89 \pm 0.3$ & $126.8 \pm 17$ & $4.64 \times 10^{4}$ \\
\hline
\end{tabular}

Fig. 4 Enzyme kinetics of AgUricases. The activities of wild-type (circle), K12C-E286C (square), and S296C-C302S (triangle) mutant AgUricase were measured by substrate (UA) depletion assays. The rate (specific activity) of UA oxidation was calculated based on the linear decrease in absorbance at $292 \mathrm{~nm}$. The data were fit to the Michaelis-Menten equation by GraphPad Prism 7 to determine the $k_{\text {cat }}$ and $K_{\mathrm{m}}$ values. The data are presented as the mean \pm standard error of the mean (SEM) of at least three independent experiments

To investigate the effect of disulfide bond formation on subunit assembly, the wild-type and K12C-E286C mutant enzymes were analyzed using the PISA program [6], and the results are shown in Table 1. $\Delta G^{\text {diss }}$ indicates the free energy of tetramer or dimer dissociation in $\mathrm{kcal} / \mathrm{mol}$. Positive values of $\Delta G^{\text {diss }}$ indicate that an external driving force must be applied to result in the dissociation of the assembly. The $\Delta G^{\text {diss }}$ values of the K12C-E286C-cross-linked dimers (A-D and B-C) increased from 33.4 and $31.5 \mathrm{kcal} / \mathrm{mol}$ to 59.1 and $49.8 \mathrm{kcal} / \mathrm{mol}$, respectively, compared with those of the relevant WT dimers, indicating that both the $A-D$ and $B-C$ dimers in the $\mathrm{K} 12 \mathrm{C} / \mathrm{E} 286 \mathrm{C}$ mutant enzyme are more difficult to dissociate than those in the wild-type enzyme.

We also analyzed the buried surface area of the wild-type and K12C-E286C AgUricase with the PISA program [6] (Table 1). The solvent-accessible areas of the WT and K12C-E286C AgUricases were $39484 \AA^{2}$ and $38389 \AA^{2}$, respectively, which were calculated based on the crystal structures. Disulfide cross-linking decreases the solvent-accessible area by $2.8 \%$, which may contribute to the improved stability of the mutant enzyme. The total buried interface areas for the wild-type and K12C-E286C enzymes were 25175 and $30069 \AA^{2}$, respectively. The buried surface areas of the monomer-monomer interfaces of the wild-type and K12C-E286C AgUricases were $7045 \AA^{2}$ (subunit A-D, WT), $7176 \AA^{2}$, (subunit B-C, WT), $8126 \AA^{2}$ (subunit A-D, K12C-E286C mutant), and $8475 \AA^{2}$ (subunit B-C, K12C-E286C mutant). The K12C-E286C mutant showed an increase in the total buried interface area of $19 \%$ and in the buried surface areas of subunit A-D and subunit B-C of $15 \%$ and $18 \%$, respectively. The increases in the buried interface areas contributed to the stabilization of the subunit assembly, leading to higher thermostability.

The overall main-chain trace of the K12C-E286C mutant was in good agreement with that of the wild-type enzyme (PDB entry 2YZB) (Supplementary Fig. S3). However, the residue ranges $11-17,258-263$, and 281-297 in the mutant structure showed different conformations compared to those in the WT enzyme 

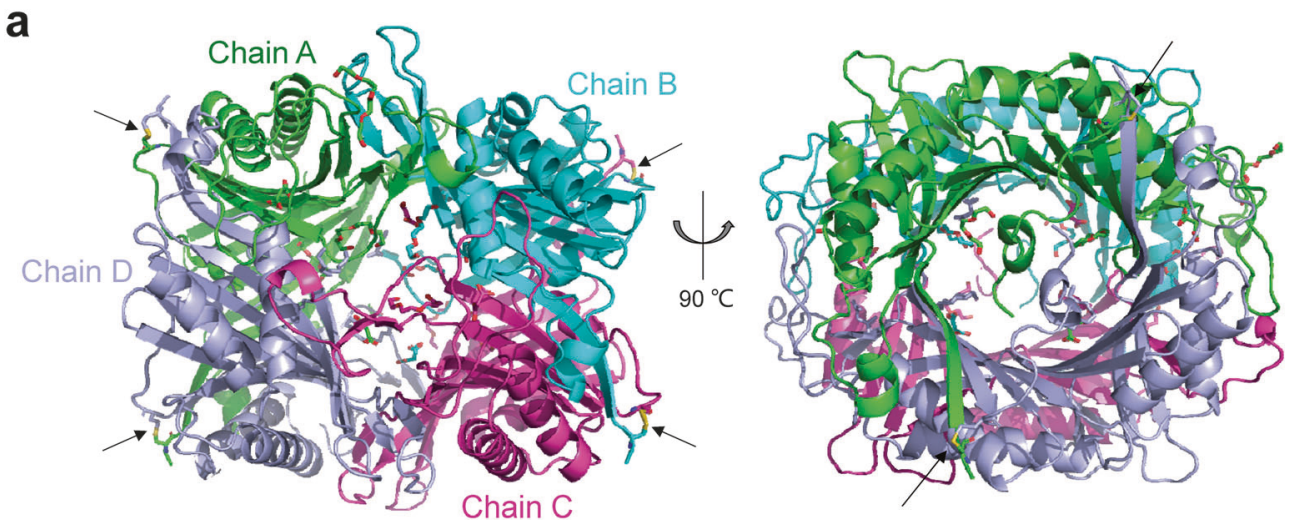

b
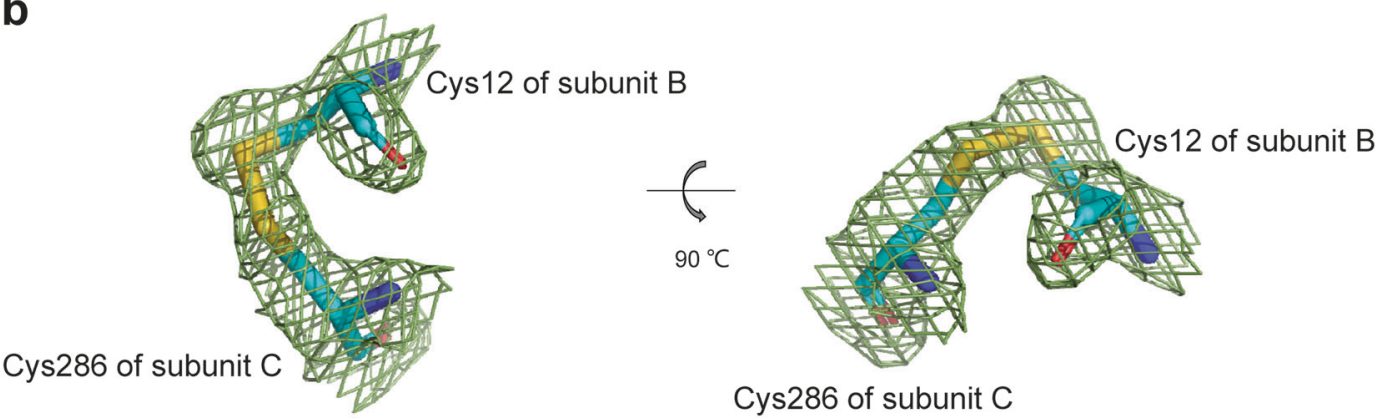

Fig. 5 Structure of the K12C-E286C AgUricase mutant. The structure of the K12C-E286C AgUricase mutant was generated with the PyMOL program (PDB entry: 6OE8). a Side and top views of the schematic model of the AgUricase tetramer: chain A (TV green), chain B (cyan), chain C (purple), and chain D (light blue). Disulfide bonds are shown in yellow and indicated by black arrows. $\mathbf{b}$ Side and top views of the $2 \mid$ Fo $|-| F C \mid$ density map of the disulfide bonds between Cys 12 of subunit B and Cys286 of subunit C. Disulfide bonds are shown in yellow

Table 1. Assembly analysis of AgUricases

\begin{tabular}{llllr}
\hline & Subunits & $\Delta G^{\text {diss }}(\mathrm{kcal} / \mathrm{mol})$ & ASA, $\AA^{2}$ & BSA, $\AA^{2}$ \\
\hline Wild-type & Tetramer & 77.6 & 39484 & 25175 \\
& A-D dimer & 33.4 & 25324 & 7045 \\
& B-C dimer & 31.5 & 25114 & 7176 \\
K12C-E286C & Tetramer & 77.7 & 38389 & 30069 \\
& A-D dimer & 59.1 & 25869 & 8126 \\
& B-C dimer & 49.8 & 25988 & 8475 \\
\hline ASA accessible surface area, BSA buried surface area, $\Delta G^{\text {diss }}$ free energy of \\
disassociation
\end{tabular}

owing to the formation of the disulfide bonds that stabilized these flexible loop regions. The dynamic movement of these flexible loop regions may affect the thermostability of AgUricase. Disulfide cross-linking between these flexible loop regions can fix their conformations, thereby enhancing the stability of the loop regions and the whole protein. The $\mathrm{K} 12 \mathrm{C}-\mathrm{E} 286 \mathrm{C}$ mutation did not affect the catalytic site of the enzyme; therefore, disulfide cross-linking had no effect on the enzymatic activity of AgUricase (Fig. 4).

The C-terminal loop affected the stability of AgUricase

Our structure showed a clear density map for the C-terminal residues 298 through 302 (Fig. 6a), which were missing in the structure of wild-type AgUricase (PDB: 2YZB) (Fig. 6b). We compared the mean B-factors of wild-type and K12C-E286C AgUricase. The mean B-factors of the residues in the C-terminal loop of wild-type AgUricase were relatively high, indicating that the C-terminal loop is highly flexible. The mean B-factors of the residues in the C-terminal loop of $\mathrm{K} 12 \mathrm{C}-\mathrm{E} 286 \mathrm{C}$ AgUricase decreased dramatically, indicating that disulfide cross-linking between $\mathrm{C} 12$ and C286 stabilized the flexible C-terminal loop (Fig. 6c). To investigate the effect of this loop on the stability of AgUricase, we analyzed the thermostability of the full-length enzyme, the C-terminal-truncated WT enzyme and the K12C-E286C mutant enzyme. TSA data showed that the Tm1 values of the wild-type and $\mathrm{K} 12 \mathrm{C}-\mathrm{E} 286 \mathrm{C}$ AgUricase decreased to $11.5^{\circ} \mathrm{C} \quad\left(50.6-39.1^{\circ} \mathrm{C}\right)$ and $7.9^{\circ} \mathrm{C}\left(52.3-44.4^{\circ} \mathrm{C}\right)$, respectively. The $\mathrm{Tm} 2$ values of wild-type $\left(72^{\circ} \mathrm{C}\right)$ and $\mathrm{K} 12 \mathrm{C}-\mathrm{E} 286 \mathrm{C}$ AgUricase $\left(83.3^{\circ} \mathrm{C}\right)$ did not change when the C-terminal residues 298-302 were removed (Fig. $6 \mathrm{~d}$ ). Our structure showed that the C-loops in subunits $A$ and $D$ and $B$ and $C$ were close; for example, the distance between S296 in chain A and S296 in chain D was $4.2 \AA$, and the distance between $\mathrm{C} 302$ in chain A and K244 in chain D was $6.7 \AA$. Therefore, the C-loops of subunits $A$ and $D$ interacted with each other and contributed to the interface of the A-D dimer and the stability of the intact AgUricase tetramer. The C-terminal truncation destroyed the C-loop interaction between the subunits, thus decreasing the stability of the intact AgUricase. These results suggest that the C-terminal residues 298-302 are required for the formation of a stable AgUricase tetramer and confirm that the K12C-E286C mutations increase the stability of the enzyme.

K244C forms disulfides with C302 and improves the thermostability of AgUricase

According to the solved K12C-E286C mutant structure, the Ca-Ca distances between K244 and S246 in one subunit and C302 in the other subunit in a dimer were $6.7 \AA$ and $6.6 \AA$, respectively, which indicates that K244 and S246 have the potential to form intersubunit disulfide bonds with $\mathrm{C} 302$ if they are substituted with cysteine (Fig. 7a). SDS-PAGE analysis showed that the K244C mutation successfully introduced disulfide bonds into both wildtype AgUricase and the K12C-E286C mutant, whereas S246C did not (Fig. 7b). The TSA results showed that K244C increased the 
a
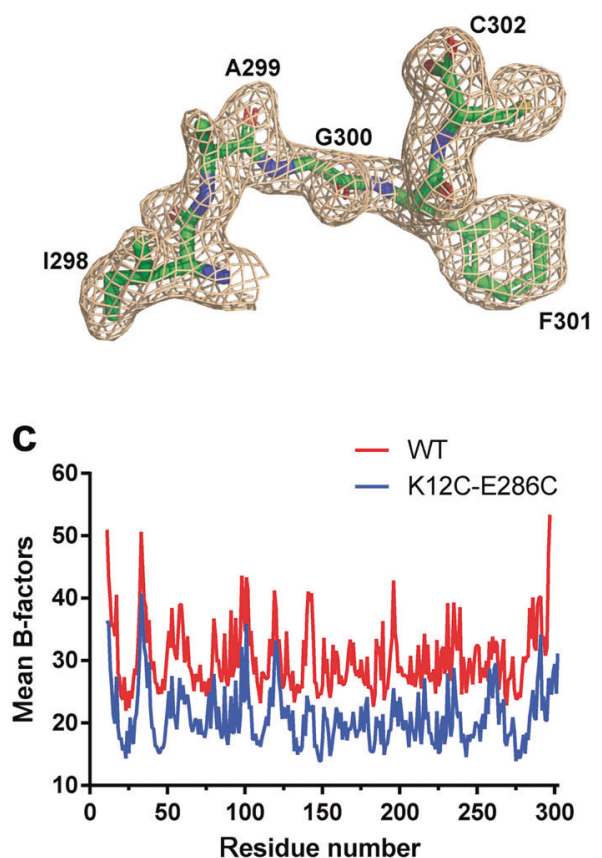

b

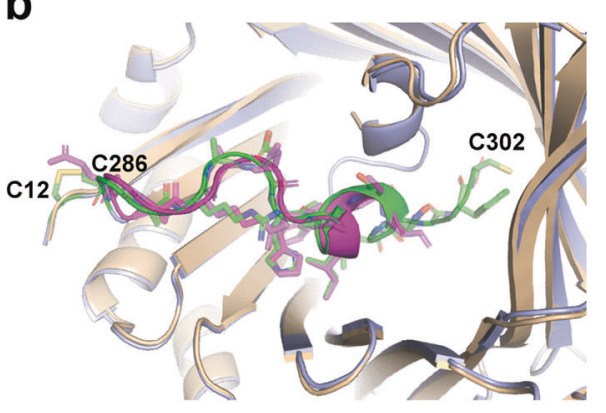

d

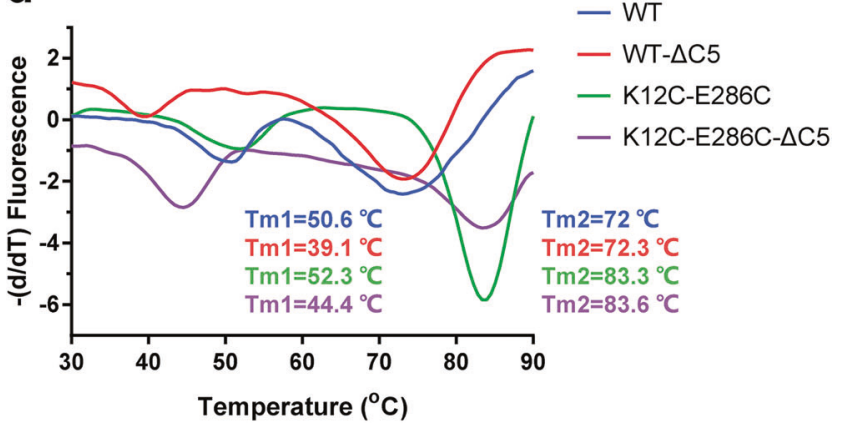

Fig. 6 A C-terminal flexible loop is required for the stability of AgUricase protein. a The $2 \mid$ Fo $|-|$ Fc $\mid$ density map of residues $298-302$ in AgUricase. b Structural comparison of the C-terminal residues 286-302 in wild-type and K12C-E286 mutant AgUricase. Wild-type AgUricase is gray, and the $\mathrm{K} 12 \mathrm{C}-\mathrm{E} 286 \mathrm{C}$ mutant AgUricase is light blue, and its C-terminal residues (286-302) are green and the disulfide bonds are yellow. c Mean B-factors of wild-type and K12C-E286C AgUricase. The mean B-factors of wild-type and K12C-E286C AgUricase were calculated according to the crystal structures of wild-type AgUricase (PDB ID 2YZB) and K12C-E286C AgUricase (PDB ID 6OE8). d Results of the thermal shift assay (TSA) of the $\triangle \mathrm{C} 5$ deletion mutant of the K12C/E286C AgUricase compared with those of the K12C/E286C AgUricase

Tm1 value by $5.9^{\circ} \mathrm{C}\left(50.6-56.5^{\circ} \mathrm{C}\right)$ and the $\operatorname{Tm} 2$ value by $6.6^{\circ} \mathrm{C}$ $\left(72-78.6^{\circ} \mathrm{C}\right)$ compared with WT AgUricase and increased the Tm1 value by $5.3^{\circ} \mathrm{C}\left(52.3-57.6^{\circ} \mathrm{C}\right)$ and the $\operatorname{Tm} 2$ value by $3.6^{\circ} \mathrm{C}$ $\left(83.3-86.9^{\circ} \mathrm{C}\right.$ ) compared with the $\mathrm{K} 12 \mathrm{C}-\mathrm{E} 286 \mathrm{C}$ AgUricase mutant (Fig. 7c). A heat resistance assay showed that the $\mathrm{K} 244 \mathrm{C}$ mutation increased the $\mathrm{Tm}$ value of WT AgUricase by $4.6^{\circ} \mathrm{C}\left(61-65.6^{\circ} \mathrm{C}\right)$ and that of the $\mathrm{K} 12 \mathrm{C}-\mathrm{E} 286 \mathrm{C}$ mutant by $3.5^{\circ} \mathrm{C}\left(75-78.5^{\circ} \mathrm{C}\right)$ (Fig. $7 \mathrm{~d}$ ). Our structure indicated that $\mathrm{K} 244 \mathrm{C}-\mathrm{C} 302$ cross-linking would fix the flexible C-loop in the AgUricase and hinder the disassociation of the dimer, thereby improving the stability of the enzyme. Our TSA and heat resistance data confirmed these hypotheses.

Disulfide cross-linking protects AgUricase from protease digestion To test whether disulfide cross-linking protected AgUricase from protease digestion, we tested the activity of AgUricases treated with Proteinase $\mathrm{K}$ at various times. Wild-type AgUricase retained $59.4 \%$ activity after 5 min of Proteinase $\mathrm{K}$ treatment, $30.1 \%$ activity after $10 \mathrm{~min}$ and $0 \%$ activity after $15 \mathrm{~min}$. The K12C-E286C mutant retained $78.3 \%$ activity after $5 \mathrm{~min}$ of Proteinase $\mathrm{K}$ treatment, $52.6 \%$ activity after $10 \mathrm{~min}$ and $6.6 \%$ activity after $15 \mathrm{~min}$, whereas the $\mathrm{K} 12 \mathrm{C}-\mathrm{E} 286 \mathrm{C}-\mathrm{K} 244 \mathrm{C}$ mutant retained $82.2 \%$ activity after $5 \mathrm{~min}$ of Proteinase $\mathrm{K}$ treatment, $54.7 \%$ activity after $10 \mathrm{~min}$ and $8.1 \%$ activity after $15 \mathrm{~min}$ (Fig. 8). These results suggested that disulfide cross-linking could protect AgUricase from protease digestion. Our structure analysis showed that $\mathrm{K} 12 \mathrm{C}-\mathrm{E} 286 \mathrm{C}$ disulfide cross-linking fixed the flexible C-terminal loop and decreased the accessible surface area of intact AgUricase, which reduced the surface area exposed to Proteinase $\mathrm{K}$, thus protecting AgUricase from protease digestion.

\section{DISCUSSION}

Thermostability is a key issue for protein drugs [5]. The disassociation of multimeric proteins into subunits is a key factor contributing to the thermostability of those proteins [28]. AgUricase is a tetramer composed of four identical subunits, and thermal unfolding of AgUricase involves multiple dissociation steps: the tetramer dissociates into dimers, the dimers dissociate into monomers, and finally the unfolding of the monomers occurs [6]. Introducing disulfide cross-linking has been proven to be a useful method to improve the thermostability and heat resistance of proteins $[6,25,26,29]$. In this study, we introduced intersubunit cysteine pair mutations into AgUricase based on its WT crystal structure (Fig. 1). The formation of the K12C-E286C and S296C-S296C monomer-monomer disulfide bonds (Fig. 2a) prevented the dimer from dissociating, resulting in an increased unfolding temperature in the second step of dissociation (Fig. 2b). The formation of these intersubunit disulfide bonds significantly enhanced the thermostability and heat resistance of this multimeric enzyme (Figs. 2 and 3), whereas avoiding any observable reduction of the enzymatic activity (Fig. 4). These observations were further confirmed by the structure of the K12C-E286C mutant. Disulfide bonds covalently cross-linked subunits $A$ and $D$ and $B$ and $C$ (Fig. 5), which increased the $\Delta G^{\text {diss }}$ values and the buried surface areas of the dimers (A-D and B-C) (Table 1) and resulted in strong dimer interfaces that required more energy to dissociate the interactions between the subunits. Disulfide crosslinking also protected AgUricase from protease digestion through fixing the flexible loops and decreasing the surface area exposed to protease (Fig. 8).

Many proteins have variable loop regions, the flexibility of which may lead to low protein stability [30]. Our structure analysis showed that the C-terminal residues 298-302 in AgUricase form a loop region. This loop region is flexible and therefore disordered in the crystal structure of wild-type AgUricase, which has no intersubunit disulfide bonds (Fig. 6a, b). The crystal structure of the $\mathrm{K} 12 \mathrm{C}-\mathrm{E} 286 \mathrm{C}$ AgUricase mutant shows that this loop region is involved in the intersubunit interface and is thus required for the 
a

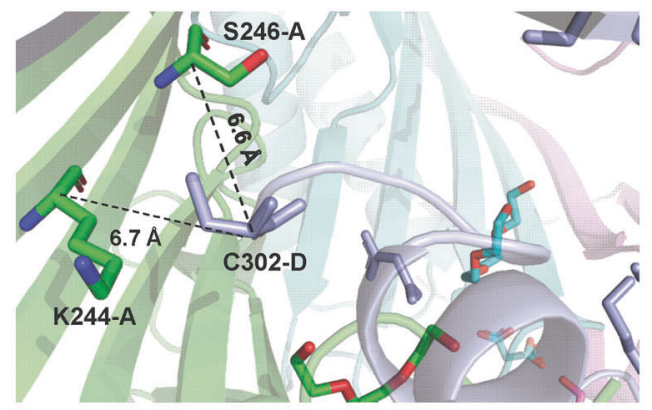

C

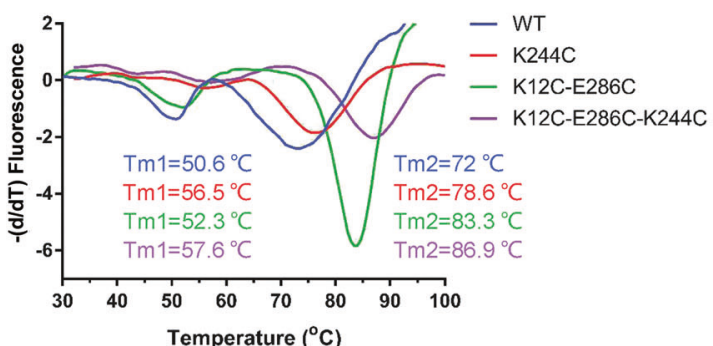

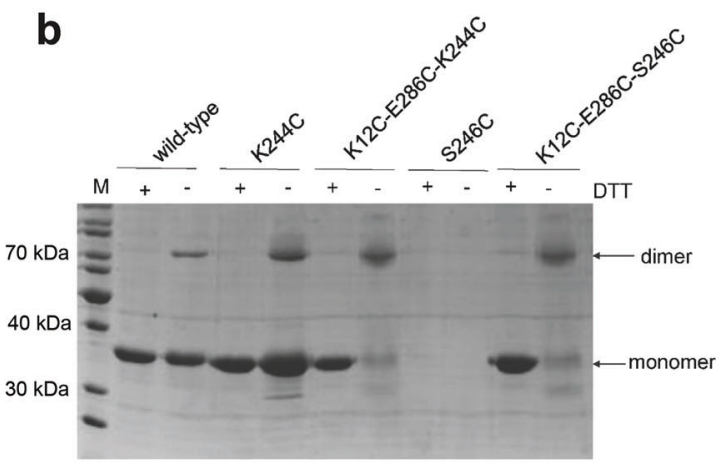

d

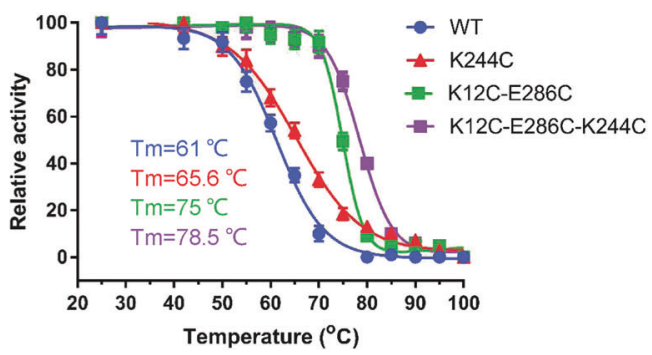

Fig. 7 K244C forms disulfide bonds with C302 and improves the thermostability of AgUricase. a C $\alpha-C_{\alpha} \alpha$ distance between K244 and S246 in subunit $A$ and $C 302$ in subunit D. b SDS-PAGE results showing that mutation K244C strengthened dimer formation between the subunits in both the WT and K12C/E286C mutant AgUricases, whereas S246C did not. c TSA results showing that the K244C mutation shifted the Tm peaks of both the WT and K12C-E286C mutant AgUricases to higher temperatures. $\mathbf{d}$ The K244C mutation increased the thermostability of the WT and K12C-E286C mutant AgUricase

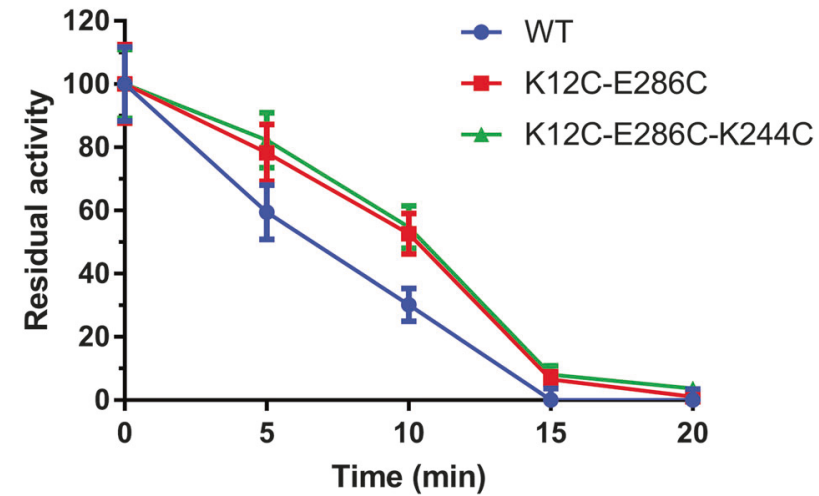

Fig. 8 Disulfide cross-linking protects AgUricase from protease digestion. Wild-type (circle), K12C-E286C (square), and K12C-E286C$\mathrm{K} 244 \mathrm{C}$ (triangle) mutant AgUricase $(80 \mu \mathrm{g})$ were treated with $20 \mu \mathrm{g}$ Proteinase $\mathrm{K}$ at room temperature, and the residual activity of AgUricase was measured at various times. The data are presented as the mean \pm standard error of the mean (SEM) of at least three independent experiments

stability of the enzyme (Fig. $6 c, d$ ). The introduction of a K244C-C302 disulfide bond, which was designed based on the crystal structure, improved the thermostability of the enzyme. The SDS-PAGE assay (Fig. 7b), TSA (Fig. 7c) and the heat resistance assay (Fig. 7d) confirmed the formation of the disulfide bond and the improvement of thermostability.

Our studies demonstrated that introducing disulfide bonds that cross-linked subunits stabilized the flexible loops and prevented the disassociation of the multisubunit protein, resulting in a mutant enzyme with significantly enhanced thermostability and heat resistance.
Over the years, a number of uricase preparations from a variety of sources have been developed for therapeutic use in the treatment of gout and hyperuricemia associated with tumor lysis in patients with malignant disease $[1,31]$. To date, two recombinant uricase preparations, rasburicase [32, 33], and pegloticase [34-37], have been approved for the management of uric acid levels in plasma. Pegloticase, a PEGylated chimeric porcine-baboon uricase, has increased thermostability, an extended serum half-life and reduced immunogenicity [38], but it still induces an immune response, which results in a loss of activity and an increased risk of infusion reactions [39]. Many of the adverse side effects of protein drugs are associated with protein stability and immunogenicity, which are considered to be the major challenges for the development of therapeutic proteins $[39,40]$. Immunogenicity is caused by various factors, including intrinsic causes, such as specific amino-acid sequences and posttranslational modifications, and extrinsic factors, including the route of administration, the dosage and, in particular, the patients' genetic profile [39-43]. The instability of proteins is also regarded as one of the highest risk factors for the immunogenicity of therapeutic proteins [40]. Improving stability can reduce the immunogenicity of therapeutic proteins. The solvent-exposed flexible loops of AgUricase are sensitive to proteases such as Proteinase $\mathrm{K}$ under in vivo conditions, resulting in the loss of enzyme activity and immune reactions. In this study, we fixed the C-terminal flexible loop of AgUricase by disulfide cross-linking to generate a mutant enzyme with increased thermal thermostability and enhanced resistance to protease digestion (Fig. 8), which may reduce the in vivo immunogenicity of the enzyme. This engineered enzyme provides a potential therapeutic uricase, but further animal model studies and clinical trials will be needed before it is used as a pharmaceutical agent. The method reported in this paper provides a common strategy that could be used for the development of protein drugs with high stability and low immunogenicity. 
In summary, we have obtained two highly stable AgUricase mutants with activity equivalent to that of the full-length WT enzyme by introducing intersubunit disulfide bonds. The disulfide cross-linking significantly increased the thermostability and heat resistance of AgUricase by preventing the disassociation of the multimeric enzyme assembly and stabilizing the flexible C-terminal loops in each subunit of the enzyme. These heat-resistant AgUricase mutants provide promising therapeutic options for the treatment of hyperuricemia-related diseases. The introduction of intersubunit disulfide bonds in multimeric protein enzymes has been shown to be a promising protein engineering strategy to increase protein stability for therapeutic uses.

\section{ACKNOWLEDGEMENTS}

This work was supported by the National Natural Science Foundation of China (31770796 to YJ); the Strategic Priority Research Program of CAS (XDB08020303 to HEX); the National Science and Technology Major Project (2018ZX09711002-002-002 to YJ); the K.C. Wong Education Foundation (to YJ).

\section{AUTHOR CONTRIBUTIONS}

HEX and YS designed the study. YS, TW, and QFL performed the experiments and analyzed the data. YS and XEZ solved the structure. YS and TW wrote the paper. HEX, $X E Z$, and $Y J$ revised the paper. All authors reviewed the results and approved the final version of the manuscript.

\section{ADDITIONAL INFORMATION}

The online version of this article (https://doi.org/10.1038/s41401-019-0269-x) contains supplementary material, which is available to authorized users.

Competing interests: The authors declare no competing interests.

Publisher's note: Springer Nature remains neutral with regard to jurisdictional claims in published maps and institutional affiliations.

\section{REFERENCES}

1. Nuki G. Uricase therapy of gout. In Gout and Other Crystal Arthropathies. Elsevier Inc.; 2012. 174-86.

2. Kratzer JT, Lanaspa MA, Murphy MN, Cicerchi C, Graves $C L$, Tipton PA, et al Evolutionary history and metabolic insights of ancient mammalian uricases. Proc Natl Acad Sci U S A. 2014;111:3763-8.

3. Abeles AM. Hyperuricemia, gout, and cardiovascular disease: an update. Curr Rheumatol Rep. 2015;17:13.

4. Nyborg AC, Ward C, Zacco A, Chacko B, Grinberg L, Geoghegan JC, et al. A therapeutic uricase with reduced immunogenicity risk and improved development properties. PLoS One. 2016;11:e0167935.

5. Jiskoot W, Randolph TW, Volkin DB, Middaugh CR, Schoneich C, Winter G, et al. Protein instability and immunogenicity: roadblocks to clinical application of injectable protein delivery systems for sustained release. J Pharm Sci. 2012;101:946-54.

6. Hibi T, Kume A, Kawamura A, Itoh T, Fukada H, Nishiya Y. Hyperstabilization of tetrameric Bacillus sp. TB-90 urate oxidase by introducing disulfide bonds through structural plasticity. Biochemistry. 2016;55:724-32.

7. Eijsink VG, Bjork A, Gaseidnes S, Sirevag R, Synstad B, van den Burg B, et al. Rational engineering of enzyme stability. J Biotechnol. 2004;113:105-20.

8. Marshall SA, Lazar GA, Chirino AJ, Desjarlais JR. Rational design and engineering of therapeutic proteins. Drug Discov Today. 2003;8:212-21.

9. Yainoy S, Phuadraksa T, Wichit S, Sompoppokakul M, Songtawee N, Prachayasittikul V, et al. Production and characterization of recombinant wild type uricase from indonesian coelacanth (L. menadoensis) and improvement of its thermostability by in silico rational design and disulphide bridges engineering. Int J Mol Sci. 2019;20:E1269.

10. Ho SN, Hunt HD, Horton RM, Pullen JK, Pease LR. Site-directed mutagenesis by overlap extension using the polymerase chain reaction. Gene. 1989;77:51-9.

11. Liu P, Jia MZ, Zhou XE, De Waal PW, Dickson BM, Liu B, et al. The structural basis of the dominant negative phenotype of the Galphai1beta1gamma2 G203A/ A326S heterotrimer. Acta Pharmacol Sin. 2016;37:1259-72.
12. Shi $Y$, Zheng $D$, Xie J, Zhang $Q$, Zhang $H$. Thermal stability of thermoanaerobacter tengcongensis ribosome recycling factor. Protein Pept Lett. 2014;21:285-91.

13. Otwinowski Z, Minor W. Processing of X-ray diffraction data collected in oscillation mode. Methods Enzymol. 1997;276:307-26.

14. McCoy AJ, Grosse-Kunstleve RW, Adams PD, Winn MD, Storoni LC, Read RJ. Phaser crystallographic software. J Appl Crystallogr. 2007;40:658-74.

15. Emsley P, Cowtan K. Coot: model-building tools for molecular graphics. Acta Crystallogr D Biol Crystallogr. 2004;60:2126-32.

16. Adams PD, Afonine PV, Bunkoczi G, Chen VB, Davis IW, Echols N, et al. PHENIX: a comprehensive python-based system for macromolecular structure solution. Acta Crystallogr D Biol Crystallogr. 2010;66:213-21.

17. Winn MD, Ballard CC, Cowtan KD, Dodson EJ, Emsley P, Evans PR, et al. Overview of the CCP4 suite and current developments. Acta Crystallogr D Biol Crystallogr. 2011;67:235-42.

18. Pikal-Cleland KA, Rodríguez-Hornedo N, Amidon GL, Carpenter JF. Protein denaturation during freezing and thawing in phosphate buffer systems: monomeric and tetrameric $\beta$-galactosidase. Arch Biochem Biophys. 2000;384:398-406.

19. Mn González, Argaraña CE, Fidelio GD. Extremely high thermal stability of streptavidin and avidin upon biotin binding. Biomol Eng. 1999;16:67-72.

20. Kurganov BI, Kornilaev BA, Chebotareva NA, Malikov VP, Orlov VN, Lyubarev AE, et al. Dissociative mechanism of thermal denaturation of rabbit skeletal muscle glycogen phosphorylase b. Biochemistry. 2000;39:13144-52.

21. Reddy GB, Bharadwaj S, Surolia A. Thermal stability and mode of oligomerization of the tetrameric peanut agglutinin: a differential scanning calorimetry study. Biochemistry. 1999;38:4464-70.

22. Bayol A, Dupin P, Boe JF, Claudy P, Létoffé JM. Study of pH and temperatureinduced transitions in urate oxidase (Uox-EC1.7.3.3) by microcalorimetry (DSC), size exclusion chromatography (SEC) and enzymatic activity experiments. Biophys Chem. 1995;54:229-35.

23. Rastegari AA, Buzari B, Bordbar AK. Thermal stability of pepsin: a predictive thermodynamic model of a multi-domain protein. Biochem Biophys Rep. 2017;9:295-301.

24. Muñoz V, Cronet $P$, López-Hernéndez $E$, Serrano $L$. Analysis of the effect of local interactions on protein stability. Fold Des. 1996;1:167-78.

25. Jeong MY, Kim S, Yun CW, Choi YJ, Cho SG. Engineering a de novo internal disulfide bridge to improve the thermal stability of xylanase from Bacillus stearothermophilus No. 236. J Biotechnol. 2007;127:300-9.

26. Nordlund HR, Laitinen $\mathrm{OH}$, Uotila ST, Nyholm T, Hytonen VP, Slotte JP, et al. Enhancing the thermal stability of avidin. Introduction of disulfide bridges between subunit interfaces. J Biol Chem. 2003;278:2479-83.

27. Fernandez-Lafuente R. Stabilization of multimeric enzymes: strategies to prevent subunit dissociation. Enzyme Microbiol Technol. 2009:45:405-18.

28. Donovan JW, Beardslee RA. Heat stabilization produced by protein-protein association. A differential scanning calorimetric study of the heat denaturation of the trypsin-soybean trypsin inhibitor and trypsin-ovomucoid complexes. J Biol Chem. 1975;250:1966-71.

29. Pecher $P$, Arnold U. The effect of additional disulfide bonds on the stability and folding of ribonuclease A. Biophys Chem. 2009;141:21-8.

30. Nagi AD, Regan L. An inverse correlation between loop length and stability in a four-helix-bundle protein. Fold Des. 1997;2:67-75.

31. Burns CM, Wortmann RL. Gout therapeutics: new drugs for an old disease. Lancet. 2011;377:165-77.

32. Vogt B. Urate oxidase (rasburicase) for treatment of severe tophaceous gout Nephrol Dial Transpl. 2005;20:431-3.

33. Coiffier B, Mounier N, Bologna S, Ferme C, Tilly H, Sonet A, et al. Efficacy and safety of rasburicase (recombinant urate oxidase) for the prevention and treatment of hyperuricemia during induction chemotherapy of aggressive nonHodgkin's lymphoma: results of the GRAAL1 (Groupe d'Etude des Lymphomes de I'Adulte Trial on Rasburicase Activity in Adult Lymphoma) study. J Clin Oncol. 2003;21:4402-6.

34. Schlesinger N, Yasothan U, Kirkpatrick P. Pegloticase. Nat Rev Drug Discov. 2010;10:17.

35. Sundy JS, Baraf HS, Yood RA, Edwards NL, Gutierrez-Urena SR, Treadwell EL, et al Efficacy and tolerability of pegloticase for the treatment of chronic gout in patients refractory to conventional treatment: Two randomized controlled trials. JAMA. 2011;306:711-20.

36. Sundy JS, Becker MA, Baraf HS, Barkhuizen A, Moreland LW, Huang W, et al. Reduction of plasma urate levels following treatment with multiple doses of pegloticase (polyethylene glycol-conjugated uricase) in patients with treatmentfailure gout: results of a phase II randomized study. Arthritis Rheum. 2008;58:2882-91.

37. Becker MA, Baraf HS, Yood RA, Dillon A, Vazquez-Mellado J, Ottery FD, et al. Longterm safety of pegloticase in chronic gout refractory to conventional treatment. Ann Rheum Dis. 2013;72:1469-74. 
38. Mandell BF. Clinical manifestations of hyperuricemia and gout. Cleve Clin J Med. 2008;75:S5-8.

39. Tao L, Li D, Li Y, Shi X, Wang J, Rao C, et al. Designing a mutant Candida uricase with improved polymerization state and enzymatic activity. Protein Eng Des Sel. 2017;30:753-9.

40. Deehan M, Garces S, Kramer D, Baker MP, Rat D, Roettger $Y$, et al. Managing unwanted immunogenicity of biologicals. Autoimmun Rev. 2015;14:569-74.
41. Chirmule N, Jawa V, Meibohm B. Immunogenicity to therapeutic proteins: impact on PK/PD and efficacy. AAPS J. 2012;14:296-302.

42. Wadhwa M, Knezevic I, Kang HN, Thorpe R. Immunogenicity assessment of biotherapeutic products: an overview of assays and their utility. Biologicals. 2015;43:298-306.

43. Kuriakose A, Chirmule N, Nair P. Immunogenicity of biotherapeutics: causes and association with posttranslational modifications. J Immunol Res. 2016;2016:1298473. 